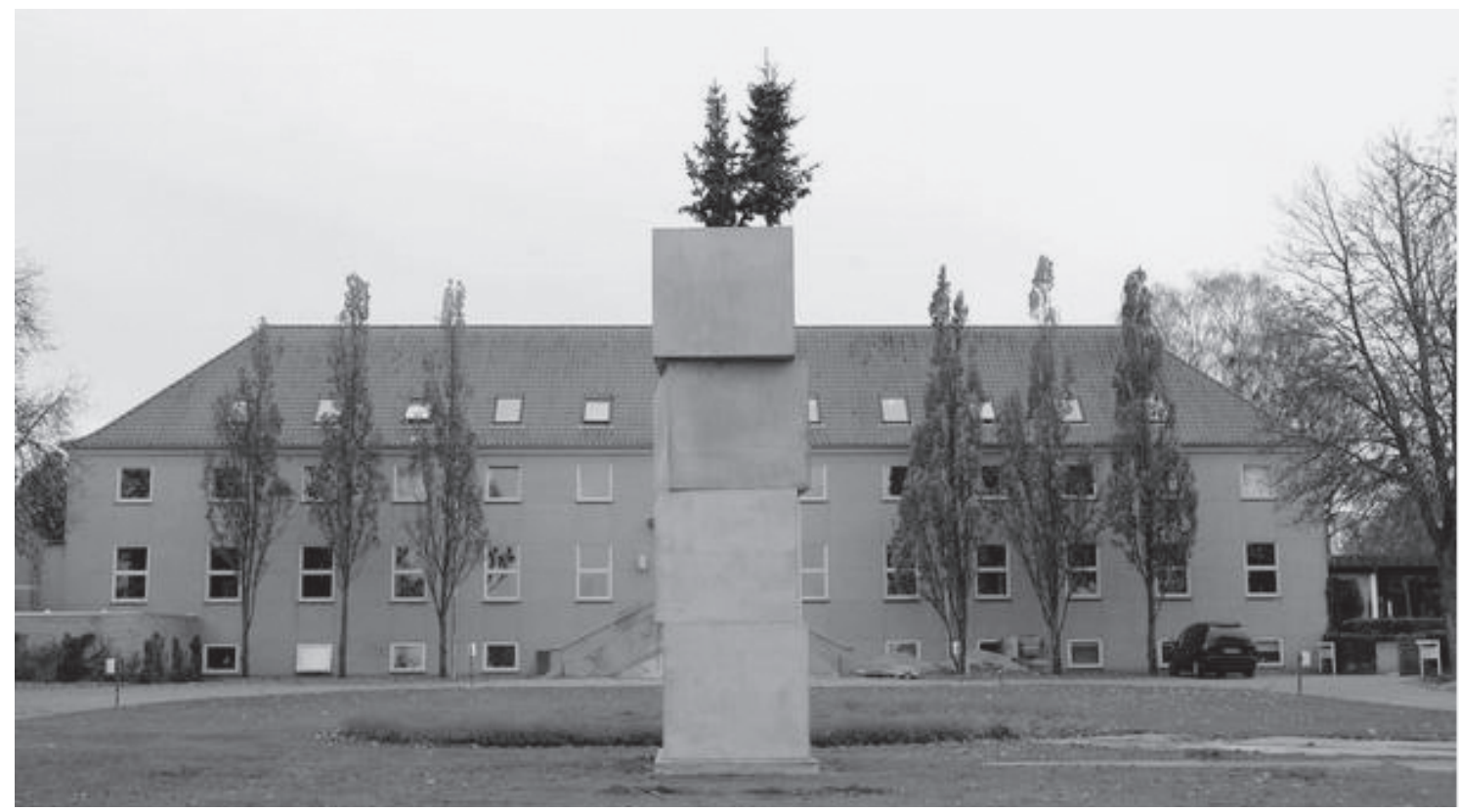

崖

\title{
Heroisme i sten? Arkitektur, ny kunst og ideologi på Gymnastikhøjskolen i Ollerup
}


"Niels Bukh overrasker stadig landet, snart som leder af verdensturneer, snart som samfundsrevser, snart som storbygmester."

(Aftenbladet, 31. juli 1933).

Der er talrige vidnesbyrd om, at billedkunst og arkitektur kan bruges af forskellige ideologiske systemer til at udtrykke eller ligefrem forherlige deres budskaber. Langt mere vanskeligt er det at afkode, om forskellige kunstneriske og arkitektoniske tegn i direkte forstand udtrykker politiske ideologier.

Gymnastikhøjskolen i Ollerup er et velegnet dansk eksempel på at analysere relationen mellem ideologi, arkitektur og billedkunst. Det er velkendt, at Gymnastikhøjskolens grundlægger, Niels Bukh, bevægede sig så langt ud af højreekstremismens tangent, at han endte med at udvikle en stærk veneration for Hitler og den nazistiske ideologi (Bonde, 2007). Det ville derfor umiddelbart være logisk, hvis hans monumentale skole i den lille sydfynske by Ollerup på Sydfyn også udtrykte totalitære og tendentielt nazistiske træk.

Den danske historiker Søren Mørch og hans kone Ritt Bjerregaard har da også givet udtryk for en sådan tolkning, idet de taler om "det øde germanske stadion”, og om Hovedbygningen, at:

Det er mere præcist (som man også gør) at kalde den 'Mussolini-' eller 'Hitler-stil', men det lyder ikke så godt. Det bærende i den er en bombastisk monumentalitet. Her er den opnået ved facadesymmetrien, en bronzefigur foran opkørselen og en meget høj pompøs trappe midt for. Hvad der foregår bag de soldateragtigt ens vinduer, kan man ikke regne ud (Bjerregaard \& Mørch, 1989: 160-163).
Historikeren Jørn Hansen og kultursociologen Søren Nagbøl afviser imidlertid, at Ollerup-anlægget skulle rumme fascistiske stiludtryk og finder, at det i hovedsagen udtrykker en mere generel neoklassisk tendens i mellemkrigstiden (Hansen \& Nagbøl, 1992: 42f).

Til forskel herfra skriver forfatteren og billedkunstneren Jørgen Minor på trods af en dyb indlevelse i anlæggets særegne atmosfære, genius loci (Norberg-Schulz, 1980: 5-23), at: "Det står ikke til diskussion, at Bukh har haft nationalsocialistiske forbilleder for sin arkitektur, og hele anloeggets symmetriske stramhed, monumentale format og de mange citater fra antikken taler et tydeligt sprog, germansk." (Minor, 2007: 5)

Hvis denne fortolkning er korrekt, var der også en god grund til, at nutidige massive indslag af kunst på Gymnastikhøjskolen i Ollerup via en generøs donation fra Ny Carlsbergfondet på 15 millioner kr. i 2004 - skulle danne en modvægt til skolens formodet autoritære stiltræk.

Indgår en sådan argumentation $\mathrm{i}$ forbindelse med de tre kunstnere Mogens Møllers, Stig Brøggers og Hein Heinsens udsmykning af Gymnastikhøjskolen? Med Hein Heinsens ord om kunstnernes idé bag deres eget arbejde: "Måske er det en dekonstruktion af fascismens cestetik?" (Jacobsen, 2004).

Ifølge Hein Heinsen var det væsentligt for de tre kunstnere at skabe et modsvar til Bukhs og anlæggets "heroisme":

"Jeg var i begyndelsen ikke meget for hele arrangementet. Stedet er specielt, og selv om indholdet er moderniseret, $m a ̊$ man reagere på historien, hvis man skal give det et monument. Man må reagere på det overidealiserede, det vidtløftige. Vi har set, hvor galt det kan ende, når man trcekker tingene for langt $u d$, og 
spørgsmålet var, om vi kunne fortalle de store historier, om vi kunne tage de store figurer frem uden at havne $i$ det heroiske." (Thøgersen, 2005: 5)

I dette og andre citater forbliver det tvetydigt, om kunstnerne vil danne modvægt til det heroisk-ekstreme ikke bare hos Niels Bukh, men også i den arkitektur, han skabte. Men hvis ikke Bukhs heroisme genfindes i hans arkitektur, bliver det så ikke meget søgt at ville skabe en kunstnerisk modvægt til noget, der altså ikke er manifesteret konkret i byggerierne?

Teoretisk er jeg inspireret af begrebsparret signifiant og signifié, der er introduceret af sprogforskeren Ferdinand de Saussure. For ham er et "tegn" kendetegnet ved en kombination af dets "udtryksside" og dets "indhold". Saussure har peget på, at udtalen af et ord som "stol" ikke står i en "motiveret" relation til ordets betydning. Relationen mellem stolens form og funktion og lyden af ordet stol er "arbitrær". I modsætning hertil er brugen af udtrykket "vovvov" for hundens gøen i høj grad "motiveret", skønt udtalen varierer lidt fra sprog til sprog (Saussure, 1986: 37).

Det, at ideologier benytter sig af forskellige retninger indenfor billedkunst og arkitektur, betyder derfor ikke nødvendigvis, at der er et "motiveret" forhold mellem bestemte former for arkitektur og specifikke ideologier, altså at de hænger uløseligt sammen, og at arkitekturen i sig selv udtrykker ideologiske træk. Når vi forledes til at tro det, skyldes det i reglen, at idemæssigt tankegods aktivt indskrives $\mathrm{i}$ arkitekturen gennem ord eller gennem fast konnoterede billedkunstneriske symboler som direkte tegn på det ideologiske budskab.

Et eksempel herpå er Foro Mussolini (Nu: Foro Italico) i Italien, et gigantisk trænings-

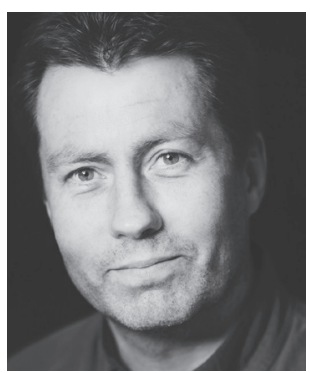

AF

HANS BONDE

kompleks designet til den fascistiske mandlige ungdomsorganisation, Balillaen, der i øvrigt inspirerede til skabelsen af Hitler Jugend i det nazistiske Tyskland. Her er Mussolinidyrkelsen direkte indføjet i arkitektur og kunst gennem fascistiske tegn og en hyldest til "Il Duce" i form af indendørs store freskomalerier, hvor Føreren taler til folket, Mussolinibuster i undervisningslokalerne, en hel bro med militaristiske relieffer og en til lejligheden skabt obelisk med indgraveringen "Mussolini Dux" (Gentile, 2007).

På grund af den massive fascistiske tegnpåvirkning kan man hurtigt danne sig den overbevisning, at selve arkitekturen også er fascistisk, men det vil være en fejlslutning. En nærmere undersøgelse viser snarere modernistiske og neoklassicistiske stiltræk. Det er faktisk ikke så underligt, fordi fascismen ikke kunstnerisk og arkitektonisk var en innovativ ideologi, men frem for alt leverede en ny sammensætning og ekstrem fortolkning af allerede eksisterende europæisk kulturgods (Thamer, 1986).

Hvis der ikke desto mindre er noget, der kan kaldes et fascistisk stiltræk, er det tendensen til gigantisme, hvis ypperste formål er at få beskueren til at føle sig uendeligt lille overfor den mægtige idé om samfundets genfødsel og i sidste ende Føreren (Gentile, 2007), som det f.eks. 
ses som led i det romerske nationalmuseum Museo della Civiltà Romana ${ }^{1}$ med dets enorme søjler, der ikke har nogen arkitektonisk funktion udover at demonstrere magtæstetik. "Ord i sten" som nazisterne kaldte det. Et eksempel på fascistisk megalomani er Hitlers og hans arkitekt Albert Speer's planer til omdannelse af Berlin til "Germania".

Jeg vil indledningsvis understrege, at jeg kan siges selv at indgå som en i hvert fald indirekte aktør i relation til implementeringen af ny kunst på Ollerup, for det første ved, at jeg i min disputats om Niels Bukh fra 2001 allerede i forordet pegede på, at: "Det er mit håb, at bogen kan medvirke til, at Gymnastikhøjskolen i Ollerup som et vigtigt kulturhistorisk monument får støtte til at restaurere anloggets mange statuer" (Bonde, 2001: 15), hvilket udgjorde hele rationalet bag Gymnastikhøjskolens første henvendelse til Ny Carlsbergfondet, og hvilket faktisk også - uhyre fortjenstfuldt af Ny Carlsbergfondet - kom til at indgå i den endelige bevilling. ${ }^{2}$

Endvidere henviser de tre kunstnere direkte til, at mine bøger har givet inspiration, f.eks. udtrykt med Mogens Møllers ord: "Det har derfor vaeret en lettelse, at få sat videnskab og ord på, sådan som professor Hans Bondes bog 'Kampen om Ungdommen' gør det - også for billedkunsten er det et meget væsentligt bidrag til forståelsen - set i det lys, som bogen kaster over begivenhederne” (Møller, 2007: 2). Som det vil fremgå, anser jeg det imidlertid for uheldigt, at kunstnerne ikke i højere grad har fordybet sig i den eksisterende arkitektur og billedkunst på Ollerup, f.eks. ud fra min disputats fra 2001, som nærværende artikels afsnit om Ollerup overvejende bygger på, og hvori tankerne bag Niels Bukhs byggerier blotlægges i detaljer, så vi kan danne os et præcist indtryk af en eventuel ar- kitektonisk "heroisme". Med "heroisk" mener jeg i artiklen en højreekstrem dyrkelse af "den stærke ener”, som var udbredt i mellemkrigstiden.

I det følgende vil jeg følge fire spor: Hvilke kunstneriske udtryk forefindes der på den oprindelige gymnastikhøjskole i Ollerup? Rummer den originale billedkunst og arkitektur på Niels Bukhs gymnastikhøjskole autoritærtheroiske træk? Kan den nye kunst på Ollerup siges at skabe et modsvar til sådanne heroiserende aspekter? Hvorledes er Ollerups kropslige dimension medtænkt i skolens arkitektur og billedkunst? For at besvare disse spørgsmål må vi først vende tilbage til tiden for gymnastikhøjskolens etablering.

\section{KROPPENS TEMPEL}

I perioden 1920 til 1926 skabte Niels Bukh et meget stort idrætsanlæg, der helt brød med proportionerne i den lille sydfynske landsby Ollerup. I 1920 kunne han indvie, hvad der var Danmarks første gymnastikhøjskole, hvilket også i byerne vakte opsigt.

Politiken beskrev bygningens nyklassicistiske inspiration: " $P a ̊$ den anden side af Fåborg landevej rejser sig Niels Bukhs gymnastikhøjskole, en enkel og smuk bygning ... i rolig nyklassisk stil med forbilleder $i$ den bedste danske bygningskunst fra overgangen mellem barok og empire." (Winding, 1923).

Gymnastikhøjskolens arkitekt Ejnar Mindedal var søn af Ollerup Håndværkerskoles forstander og overtog posten som forstander på skolen fra 1932 (Weilbachs Kunstnerleksikon, 1994). Ejnar Mindedal var en nyklassicistisk orienteret arkitekt med rødder i stilretningen "Bedre Byggeskik", der var inspireret af ældre danske byggetraditioner med vægt på håndværksmæssig kvalitet (Floris, 2005). 


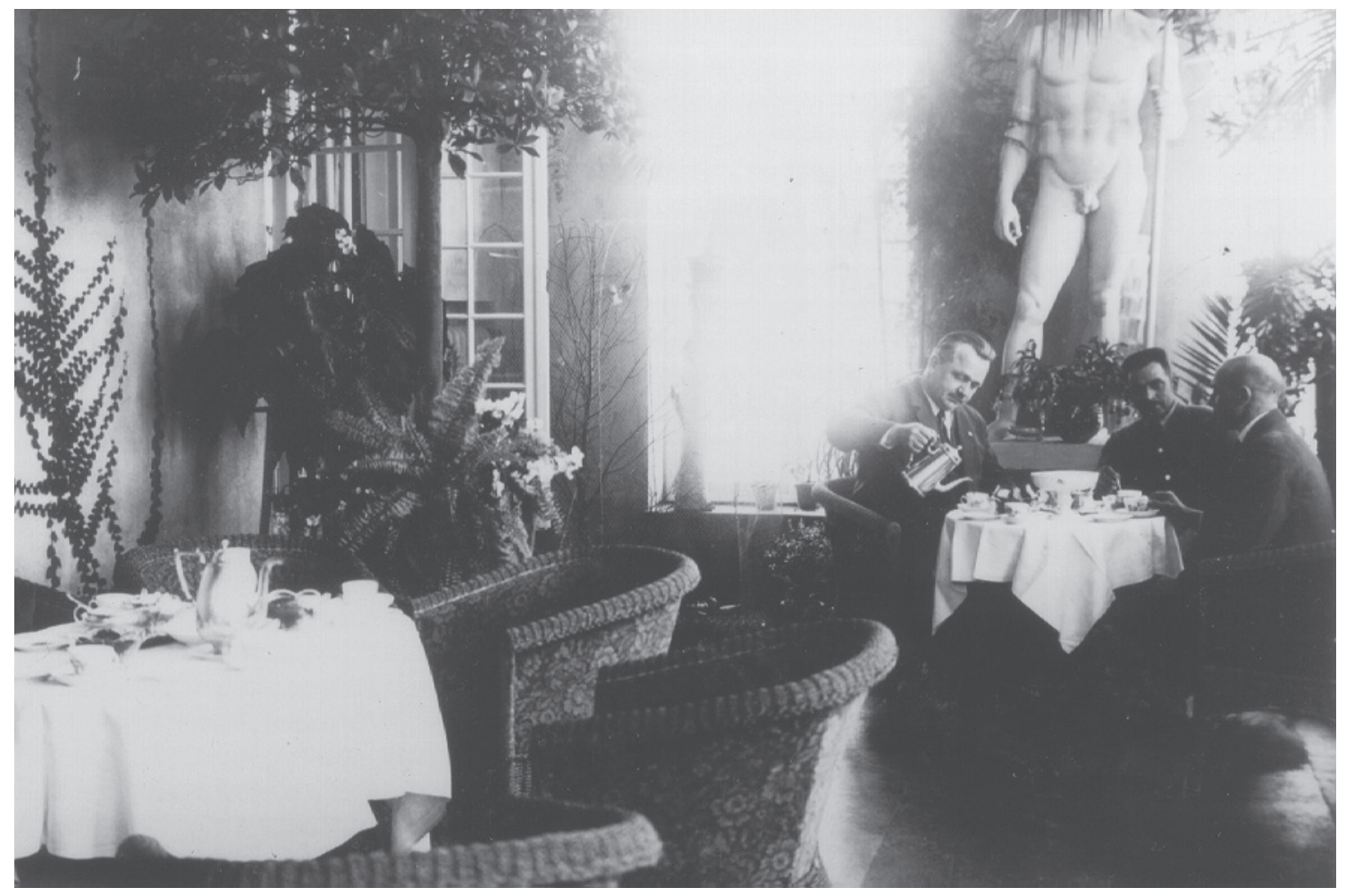

Bukhs vinterhave. (Foto: Gymnastikhøjskolen i Ollerup)

Mindedals første større opgave blev Gymnastikhøjskolen i Ollerup, men han blev i løbet af 1930'rne i takt med Bukhs voksende veneration for fascismen én af Bukhs skarpeste kritikere.

På skolen var der udover kunstneriske indslag af oldnordisk mytologi fremfor alt tale om neoklassicistisk inspiration f.eks. i de mange antikke udendørs statuer ikke mindst af kvindefigurer såsom Venus fra Milo, Damen fra Herculanum og "Såret Amazone". Bagved hovedbygningen ved dammen blev en statue af Jagtens gudinde Diana placeret og i 1937 fik
Niels Bukh af Ny Carlsbergfondet foræret statuen "Ung pige i bronze" af Volmer Bahner. Indenfor kom statuer af unge græske mænd til at dominere, og i selve gymnastiksalen blev Aksel Bredsdorfs store maleri af nøgne "unge græske krigere" ophængt og dannede baggrund for Bukh, når han underviste (Aarsskrift, 1928).

I Bukhs private stuer var der i hans vinterhave lige bag kaffebordet opstillet nogle gange én, andre gange to store nøgne græske mandsstatuer. I 1928 var der således i vinterhaven opstillet en statue af krigsguden Ares og én af 
en "hvilende satyr" (Aarsskrift, 1928), der dog blev fjernet omkring $1930^{3}$, sandsynligvis fordi mistanker om Bukhs homoseksualitet i stigende grad indebar en risiko for ham.

Også på malerier hyldedes den antikke maskulinitet, og i skolens forhal ophængtes to neoklassicistiske relieffer, præget af unge krigere. Det var brudstykker af Thorvaldsens frise af Alexander den Stores indtog i Babylon, som Napoleon Bonaparte spejlede sig i, og som han derfor bestilte en frise af fra Thorvaldsens hånd til udsmykning af Quirinale i Rom, som Napoleons tropper havde erobret.

Med fare for at trække pointerne for langt forekommer det tankevækkende, at Bukh med sin begyndende kritik af demokratiet og sin evne til at bygge magt på sin karismatiske fremtoning netop fik opsat en frise, der indirekte hyldede både den Alexander den Store, der endegyldigt i kølvandet på sin far Filip 2's erobringer, besejlede det græske demokratis skæbne, og den Napoleon, der endegyldigt erstattede den franske revolutions frihedsidealer med en dyrkelse af sin egen kejserværdighed. ${ }^{4}$ Var det et modtræk til en sådan autokratisk gestus fra Bukhs side, at skolens faste stab på Bukhs 70 års-dag i 1950 ganske kort før hans død forærede ham to relief-udsnit fra Parthenonfrisen (Frost, 1952: 22f.), der blev opført 447-438 f.Kr. på initiativ af demokraternes leder Perikles, og som siden er blevet et vartegn på det antikke athenske demokrati?

Skolens nyklassicisme fik altså både et ansigt udadtil og et ansigt indadtil. Gennem billedkunst og skulpturer udtryktes implicitte budskaber. Det kvindelige islæt var især stærkt symbolsk markeret i kraft af Carl Bonnesens både ynde- og kraftfulde rytterstatue af den “ridende amazone" fra 1931, der var opstillet foran hovedbygningen omskranset af et blomsteranlæg med bogstaverne "O.D.”, der både stod for Ollerup Delingsførere og "Ord og Dåd”, mens skolen indadtil og særlig i Bukhs stuer også kunne opfattes som præget af den homoseksuelle Bukhs fascination af mandlig æstetik, en association, der imidlertid primært kan have været bevidst for de relativt få i inderkredsen, der kendte hans seksuelle præferencer. For andre må skolen vel blot have virket som stærkt nyklassicistisk, kropslig og "frigjort" i dyrkelsen af antik nøgenhed.

Bukhs komplementære dyrkelse af mandligt og kvindeligt kan ses i lyset af Erving Goffmans begrebspar frontstage og backstage (Goffman, 1966: 199) Goffmans teatermetaforik fokuserer på, at der både kan være noget, der er officielt og noget, der er skjult i en kultur. I Bukhs tilfælde er der en heteroseksuel markering udadtil og en homoseksuel indadtil, der samtidig giver et ukonventionelt mere generelt kønsrollespil mellem dyrkelsen af det kvindelige (ude) og dyrkelsen af det mandlige (inde). Den ydre markering af kvindelighed kan også opfattes som et skjold (jvf. "amazone”), der værner Bukhs intime hemmeligheder.

Bukhs succes med at etablere sin pompøse gymnastikhøjskole afhang i høj grad af hans evne til at samle bred politisk opbakning for sin sag dels fra lokale folk fra Sydfyn, der hjalp ham med gratis arbejde, til småinvestorer, dels fra Venstres rigsdagsgruppe og fremfor alt Sigurd Berg, der kort tid efter blev indenrigsminister i Venstreregeringen Neergård. Berg opnåede også støtte fra stærke kræfter i den radikale regering samt fra enkelte centralt placerede socialdemokrater.

Skolen blev altså finansieret på baggrund af en bred partipolitisk indsats, og først i 1922 kom 
de første tegn på, at Bukh vendte sig bort fra det partipolitiske system (Bonde, 2001: 167-183).

3 år efter Gymnastikhøjskolens grundstensnedlæggelse kunne Niels Bukh i 1923 indvie sit store stadion, som han lod omkranse af klassiske statuer. Opførelsen af et stadion var et udtryk for, at Bukh gav by-sportens discipliner en central placering. Som så mange af Bukhs byggerier var der altså en funktionalistisk idé bag, hvor formen skulle give den idrætslige funktion bedst mulige betingelser.

I lighed med skolens romantiske og pertentligt holdte anlæg i engelsk have-stil var stadionet tegnet af en central fornyer af dansk havekunst, den københavnske landskabsarkitekt G.N. Brandt (Stephensen, 1994). Politiken indfangede igen anlæggets nyklassicistiske præg, herunder ikke mindst de mange statuer, hvoraf nogle stod placeret helt ud mod landevejen, så de gav indtryk af at være forposter i et antikt græsk eller romersk anlæg: "Midt $i$ det fynske højland, der begynder en mils vej vest for Svendborg, skarer chausséen gennem et terroen, der henleder tanken på oldtidens Attika og Peloponnes." (Bonde, 2001).

Bukhs nybyggerier i 1920'erne kulminerede med indvielsen af Skandinaviens første overdækkede svømmehal i 1926. Igen var der nyklassicistisk inspiration, og igen stod Mindedal Rasmussen fra Håndværkerskolen som arkitekt. For sit arbejde modtog han en sølvmedalje ved De olympiske leges arkitektkonkurrencer i Amsterdam 1928.

Også i dag anerkendes svømmehallens arkitektur. Dr.phil. Esther Nyholm finder, at svømmehallen er bygget i "en klar og monumental stil, der virker med samme overbevisning $i$ dag ... Pludselig finder man her på Fyn en original og borekraftig anvendelse af klassiske ele- menter, enkle lidt lavstammede doriske søjler, hvide pilastre ned over okseblodsfarvede vagge, smukt lavt hvoelvingsloft med lysindfald og rolige proportioner"(Kristensen, 1996: 557). På baggrund af en generøs bevilling på 18 millioner kr. fra Fonden Realdania og Kulturarvsstyrelsen i 2005 er svømmehallen nu blevet ført tilbage til sin oprindelige stand fra 1926, samtidig med at den er blevet til en moderne og fuldt funktionsdygtig svømmehal ${ }^{5}$.

I 1920'erne kom Niels Bukh i tæt kontakt med gymnastikkredse i tysktalende lande. Et muligt tegn på Bukhs inspiration fra tyske og/eller østrigske völkische højre-ekstreme og arisk orienterede kredse er, at han ved etableringen af sin indendørs svømmehal i 1926 fik indlagt en stor svastika-mosaik i terrazzogulvet ved indgangen til svømmehallen. ${ }^{6}$ Tegnet kan imidlertid også være tilfældigt valgt af svømmehallens arkitekt - den såre demokratisk indstillede Ejnar Mindedal Rasmussen.

Der er selvfølgelig også en mulighed for, at Niels Bukh eller Mindedal anvendte svastikaet som et udtryk for den grundtvigske nordiskmytologiske 1900-talsarv. Også fra Danmark kendes svastikaet f.eks. på runestenen fra Snoldelev (Guirand, 1978).

I slutningen af juli 1933 midt under landbrugskrisen kunne Niels Bukh føje endnu en imponerende facet til sine monumentale byggerier $i$ form af en ny idrætshal og et udendørs svømmebassin. Han havde nu skabt et anlæg, hvis proportioner selv i hovedstaden ville forekomme store eller med Aftenbladets ord: "Niels Bukh har rejst en idrcettens domkirke, men han har bygget den i en landsby" (Aftenbladet, 31. juli 1933).

Når Bukh byggede så stort var det, fordi han agtede at gøre Gymnastikhøjskolen til et internationalt centrum for kropskultur. Som 
det afgørende tegn herpå planlagde han at afholde en international gymnastikfest af hidtil usete dimensioner, som skulle udkonkurrere De olympiske lege, en idé han allerede var begyndt at udvikle efter OL i Paris i 1924 (Nielsen, 1950: 162).

Oprindeligt var Idrætshallen planlagt i markant nyklassicistisk stil næsten som et Parthenon, men opførelsen af en buet tagkonstruktion nedtonede det klassiske indtryk, der kun blev opretholdt via en udvendig søjlerække, og i det hele taget blev bygningen præget af billige materialer og brød med det øvrige anlæg ved mest af alt at ligne et gigantisk kornlager. Der var plads til 8000 personer og en ophøjet balkon til Bukh, når han dirigerede gymnasterne. Bukh var kendt for som gymnastikleder at stille sig op på et podium, hævet over gymnaster og publikum. Praktisk var denne hævelse begrundet i de store elevhold, hvor de bagerste piger ingen chance havde for at se ham, hvis han stod på jorden, men samtidig bidrog den ved gymnastikopvisninger og de utallige pressefotos til Bukhs "ophøjede" karisma. ${ }^{7}$

Allerede før Hitlers magtovertagelse i januar 1933 havde Bukh følt, at hans egne autoritære og politisk korporative ideer i høj grad var kompatible med den tyske nazisme og dens førerdyrkelse.

Dog stod langt hovedparten af Bukhs byggerier færdige inden denne politiske radikalisering. Og Bukhs pronazistiske holdninger kom først til offentlighedens kendskab i oktober 1933. Det er derfor vanskeligt at hævde, at offentligheden på tidspunktet for opførelsen af Idrætshallen skulle have associationer i retning af, at hallen og de tidligere byggerier skulle have forbindelse til Bukhs accelererende nazistiske udskridning.

\section{"MELLEM STEN OG ÅND"}

Denne overskrift udgør titlen på de tre kunstnere, Hein Heinsens, Stig Brøggers og Mogens Møllers nye udsmykning af Gymnastikhøjskolen i Ollerup. Hein Heinsen forklarer:

"I Ollerup er der store monumentale bygninger omkring en lang akse fra nord til syd. Søjlerne foran den store gymnastikhal er umenneskelige - tom geometri. På begge sider af aksen står de ideale legemer $i$ sten. Det er udvekslingen mellem de yderliggående elementer, den alt for døde sten, den alt for ideelle ånd og den sårbare krop midt imellem, der er vores varkers tema." (Jacobsen, 2004)

Som led i kunstnernes vision for en nord-sydaksialitet er skolens oprindelige vartegn, "Den ridende amazone", som har været placeret på skolen siden 1931, blevet flyttet væk fra sin markante placering foran hovedindgangen og over på den anden side af landevejen, hvor den er blevet løftet højere op på en græsk antikt inspireret sokkel. På amazonens oprindelige sted har Stig Brøgger nu opført værket Omorica “en otte meter høj betonskulptur og ovenpå den en 2,3 meter høj bronzeskulptur formet som et par grantrceer." (Jacobsen, 2004).

For mig at se har kunstnerne hermed helt overset det væsentlige ved Niels Bukhs akse i form af det kønslige aspekt, hvor der var en meget fin balance mellem det maskuline indenfor $i$ hovedbygningen og det feminine i form af kvindelige statuer og især "Den ridende amazone" foran bygningens indgangsparti. Den ridende amazone indgik altså i en akse med en central spænding mellem homo- og heteroseksualitet, mellem kvindelighed og mandlighed, mellem løssluppenhed og kontrol, som nu er brudt. Amazonen kunne helt konkret opfattes som en styrkelse af skolens signal til potentielt ængste- 


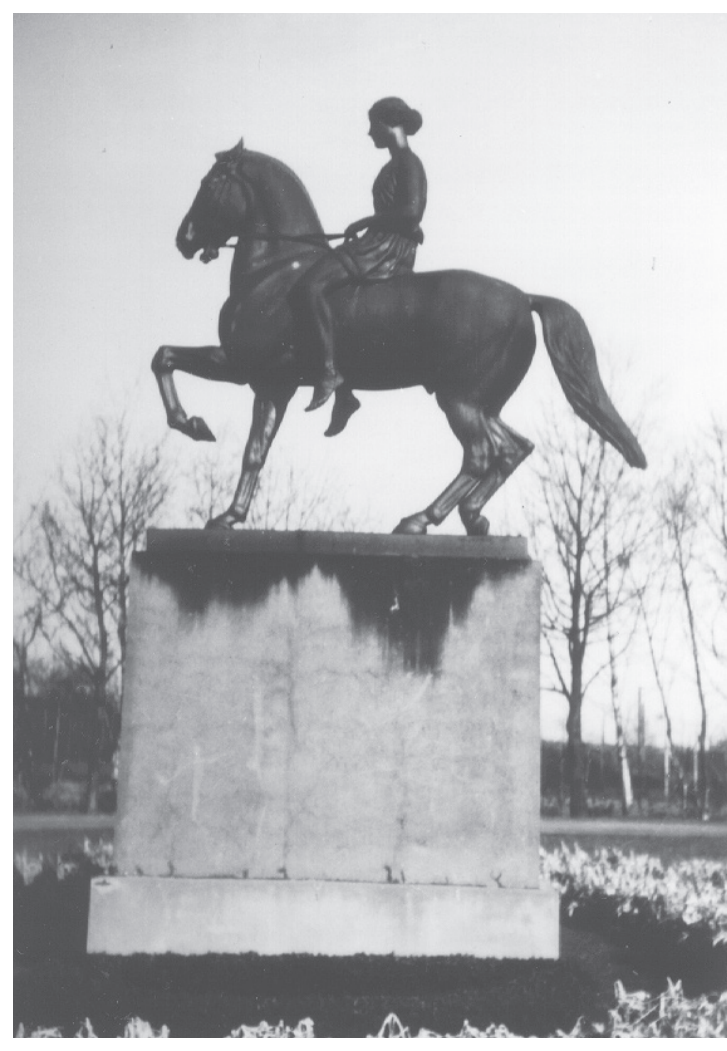

Ridende amazone. (Foto: Gymnastikhøjskolen i Ollerup)

lige forældre til kommende elever om, at på Ollerup holdt man sig på dydens smalle sti.

Fjernelsen af den ridende amazone virker derfor ikke velmotiveret, men hvad med opstillingen af Stig Brøggers Omorica med dens små træer på toppen af fire enorme forskudte blokke? Herom siger en anden af de tre kunstnere, Mogens Møller, vel mest af alt med inspiration fra kunstnernes eksplicitte postmodernisme:

"Stig Brøggers, OMORIKA (grantrceets

navn) har nu indtaget sin rette placering som tegn på højskolens nutidige placering som et avanceret loeringssted for legemsøvelser. Skulpturen er almen - men den er også på dette sted en udfordring til at opnå det tilsyneladende uopnåelige. Klippeafsatsen, den nordiske gran, et Caspar David Friedrich-billede Eller John Wayne, der er droppet ud af .......kompagniet, på vej mod det ukendte, mod nye horisonter, eller måske snarere noget, vi ikke kan nå?” (Møller, 2007: 4)

Hermed er vi faktisk fremme ved det centrale i kritikken af de tre kunstneres værker, for på trods af Mogens Møllers forsøg på at fremhæve Omorikas relation til, hvad han i en noget gammeldags term kalder "legemsøvelser", må skulpturen nøgternt betragtet siges at være blottet for referencer til menneskekroppen, og han har i stedet givet os massive, hårde $\mathrm{og}$ kantede, stablede betonblokke med et par søljegranner på toppen.

Hvor den ridende amazone direkte henviste til køn og kropslige færdigheder, er Omorika blottet for konnotationer til noget menneskeligt. Som vi vil se i det følgende har de tre kunstnere slet ikke taget udgangspunkt i deres genstand; En gymnastikhøjskole, og de har derfor ikke tematiseret menneskekroppens potentialer gennem deres kunst. I stedet har de med udgangspunkt i deres fælles idealer om "scale art" ${ }^{\prime}$ snarere interesseret sig for at fremholde store klart pointerede akser og herefter indsat kunst baseret på deres egne traditionelle ideer.

I modsætning til Bukhs motiverede kunstvalg med udgangspunkt i (krops)kulturens historie, er de tre kunstneres arbejder kropsligt referenceløse, og kun vage postmodernistiske tanker forsøger at etablere en relation mellem kunst og krop. Har de tre kunstnere i virkeligheden videreført en traditionel finkulturel foragt for 
kroppen, som Bukh eksplicit forsøgte at gøre op med gennem sin banebrydende blanding af åndelige og kropslige fag på sin højskole?

Stig Brøgger har dog fortjenstfuldt som den eneste af de tre kunstnere direkte tematiseret kroppen i sit store vægmaleri på Idrætshallens bagvæg: "From Here to There", der i værkets fokus nyfortolker antikkens mest kendte statue af en idrætsmand: Myrons diskoskaster.

Også Mogens Møllers store bronzevaser på ti meter høje søjler, der i andre former kan ses ved udsmykningen af Det Kongelige Biblioteks have, ikke mindst $\mathrm{i}$ form af den 8 meter høje "Bogens Monument", og ved Gudenåen og på Aksel Torv, kan siges at skabe en forbindelse til antikkens amforaer. Desværre er vaserne ikke i Hellas' ånd bemalet med antikke løbere eller brydere i aktion.

Mest umotiveret forekommer Hein Heinsens “De 7 Visere - og 1 tilskuer", der er visuelt dominerende, enorme betonelementer formet som en omvending af bogstavet "L".

Mellem "De 7 Visere" er der, som Møller nævner, placeret "1 tilskuer", som virker uendelig lille, idet bronzeskulpturen ser op til de monumentale visere. Personen fremstår i sin forvredne, metalliske form langt fra heroisk, men det gør til gengæld den monumentalitet, hans blik søger op imod.

"De 7 Visere" skal pege hen mod syv forskellige lokaliteter af betydning i den vestlige kulturkreds, herunder så forskellige byer som Jerusalem, Rom, Los Angeles (på grund af Hollywood), New York (associerende til angrebet på World Trade Center), Athen og Utopia, som folkeviddet i øvrigt hævder snarere peger mod Ballen nede ved kysten (Minor, 2007).

Valget af Athen kan synes velmotiveret, hvis der hermed skal skabes associationer til det antikke athenske demokrati, men så skulle det vel ikke være gudernes bolig, Parthenon, men anlægget for folkeforsamlingen, Pnyx-højen overfor Parthenon, der pegedes imod? Valget af Rom virker tankeløst. Ud over at Rom kan associere kejsermagt erstattedes den græske potentielt demokratiske sport for alle frie mænd (Miller, 2000) i Romerrigets metropol i vidt omfang af passiviserende hestevæddeløb og gladiatorkampe, hvor mænd kæmpede ultimativt til døden til fornøjelse for et blodtørstigt publikum (Köhne \& Ewigleben, 2000). Også fravalget af Olympia er bemærkelsesværdigt. Hvis kunstnerne virkelig ville skabe værker i pagt med stedets ånd ville Olympia da være det mest oplagte sted, her hvor oprindelsen til den europæiske idé om kropslig kappestrid (agon) for alvor blev kickstartet gennem etableringen af de antikke olympiske lege i 776 f.Kr.

\section{DEN GODE VILJE}

Konkluderende peger Hein Heinsen monumentale værk "Syv visere" mest af alt hen mod det største paradoks i relation til den nye kunst på Ollerup: De tre kunstnere ville skabe en modvægt til Niels Bukhs og gymnastikhøjskolens oprindelige "heroisme", men de har selv gennem Mogens Møllers højt hævede vaser, Stig Brøggers "Omorica” og Hein Heinsens "De 7 Visere" skabt en langt mere himmelstræbende og ansigtsløs kunst end Niels Bukh og hans arkitekt Mindedal nogensinde har implementeret. Det kunstnerne ville fjerne, er de helt mod hensigten kommet til at skabe. Den gode vilje slår om i sin modsætning.

Analysen af Bukhs livsværk, Gymnastikhøjskolen i Ollerup viser, at der hverken hos bevillingsgiverne, pressen, arkitekter eller hos de involverede politikere kan spores tendenser i retning af at promovere eller fortolke Gymnastikhøjskolens overvejende arkitektur og bil- 
ledkunst som hverken heroiserende endsige totalitær.

Imidlertid er der tegn på, at Bukh allerede fra begyndelsen af 1920'rne bevægede sig væk fra det parlamentariske demokrati måske inspireret af tysk-völkische kredse, der også kan have været inspirationskilde til svastikategnet ved indgangen til svømmehallen. Billedkunst som svastikaet samt reliefferne af Alexander den Stores indtog i Babylon, og arkitektoniske indslag som den imposante trappe op til hovedbygningen og den gigantiske idrætshal med ophøjet podium til Bukh er de sparsomme eksempler, der arkitektonisk-kunstnerisk kan tolkes som tegn på "heroiserende" stiltræk på Gymnastikhøjskolen.

Bukhs politiske hældning mod nazismen skete da også først for alvor med hans opvisning i Berlin i oktober 1933, efter at næsten alle hans byggerier var på plads.

I nærværende artikel er arkitektur blevet set som relativt ideologineutral. En ideologi som fascismen har ikke fornyet arkitekturen, men benyttet sig af blandingsformer af forskellige stilarter som neoklassicisme og modernisme. Den fascistiske hang til gigantisme i arkitekturen kan dog ses som et forsøg på at gestalte magten og Føreren som massiv og urokkelig og som uendeligt meget større end det enkelte individ. Ord og kunstens symboler ses til gengæld at indlejre kulturelle meddelelser i arkitekturen, hvilket i nærværende artikel i særlig grad er belyst gennem kunstens kønslige konnotationer.

Tillad mig til sidst en personlig bemærkning. Der er i dag en stærk trend indenfor arkitektur og havekunst til at forsøge at føre anlæg tilbage til deres oprindelige form. Dette var jo også f.eks. grundtanken bag renoveringen af den indendørs svømmehal på Ollerup i 2006. Det forekommer derfor som et paradoks af de store, at skolens vartegn, Den Ridende Amazone, er blevet flyttet. Lad os af respekt for de oprindelige kulturhistoriske mønstre i det mindste få hende tilbage på sin plads, så vi igen kan nyde Bukhs subtile sceniske spil mellem indre og ydre, mellem mand og kvinde og mellem forskellige seksualiteter.

\section{REFERENCELISTE}

Achen, S. T. (1986). Symboler - hvad er det? København: Gads Forlag.

Biedermann, H. (1991). Gads Symbolleksikon (oversat af Knausers 'Lexikon der Symbole'). København: Gads Forlag.

Bjerregaard, B., \& Mørch, S. (1989). Danmark, Fyn med omliggende øer. København: Gyldendal.

Bonde, H. (2001). Niels Bukh. En politik-ideologisk biografi. Bind 1: Danmarks store ungdomsfører (1880-1939), bind 1l: Ikaros fra Ollerup (1940-1950). København: Museum Tusculanums Forlag.

Bonde, H., (2007). Niels Bukh - En politisk-ideologisk biografi (CD-rom). København: Museum Tusculanums Forlag.

Floris, L. (2005). Bedre byggeskik. Bevagelse og bygninger, Holbæk Museum/Thaning \& Appel.

Frost, A. (1952). Gymnastikhøjskolens kunstværker, II, Aarsskrift, Gymnastikhøjskolen: Ollerup. s. 13-26.

Gentile, E. (2007). Fascismo di pietra. RomaBari: Laterza. 
Goffman, E., Behavior in Public Places, New York, 1966.

Guirand, F. (1978). New Larousse Encyclopedia of Mythology. London: Hamlyn.

Hansen, J., \& Nagbøl, S. (1992). Ollerup Gymnastikhøjskole - Livsrum - bevægelseskultur og social identitet. Idrcetshistorisk Årbog, s. 21-44.

Jacobsen, F. (2004, 10. marts). Skole mellem Sten og Ånd. Fyns Stiftstidende. http://www.fyens.dk/ article/31447:Svendborg-Skole-mellem-sten-ogaand

Kristensen, P. (red.) (1996). De olympiske: biogra$f i$ af de danske OL-deltagere, 1896-1996. København: Danmarks Idræts-Forbund og Danmarks Olympiske komité.

Köhne, E., \& Ewigleben, C. (2000). Gladiators and Caesars. The Power of Spectacle in Ancient Rome. Berkeley \& L.A., CA: University of California Press.

Miller, S.G. (2000). Naked Democracy. I P. Flensted-Jensen, T.H. Nielsen, L. Rubinstein (red.), Polis \& Politics. Studies in Ancient Greek History (s. 277-296). København: Museum Tusculanums Forlag.

Minor, J. (2007, 29. april). Monumentale fnis. Kronik i Politiken. Politiken. http://politiken. dk/debat/ECE299783/monumentale-fnis/
Møller, M., (2007, 19. april). “Tale til Ollerup Gymnastik Højskoles indvielse af Stig Brøgger, Hein Heinsen og Mogens Møllers nye værker og restaurering af 10 antikke skulpturer", 19/4, 2007 (privatkopi af vedhæftning til mail fra Gymnastikhøjskolen til Hans Bonde)

Nielsen, R. (1950). Niels Bukh. København.

Norberg-Schulz, C. (1980). Genius Loci: Towards a Phenomenology of Architecture. London: Academy Editions Ltd.

Saussure, F.D., "The Linguistic Sign«, i: Innis R.E., Semiotics, Indiana, Bloomington, 1986.

Stephensen, L. S. (1994). Tradition og fornyelse i dansk havekunst. Humaniora, 1, 3-8.

Thamer, H.-U. (1986). Verführung und Gewalt: Deutschland 1933-1945. Berlin: Siedler Verlag.

Thøgersen, B. (2005, 16. december). Kunst: Mammutkunst til højskole. Politiken, s. 5.

Weilbachs Kunstnerleksikon (1994). Opslag om Ejnar Mindedal Rasmussen fra online-udgaven: https://www.kulturarv.dk/kid/VisWeilbachRefresh.do?kunstnerId=9434\&wsektion $=$ alle

Winding, A. (1923, 4. september). Niels Bukhs Amerikahold. Politiken.

Aarsskrift Gymnastikhøjskolen i Ollerup (Ollerup, 1928). 


\section{(ENDNOTES)}

1 Tegnet af arkitekterne Pietro Ascheri, D. Bernardini og Cesare Pascoletti fra 1939-1941.

2 Af ansøgningen fremgår det, at: "Der ansøges om støtte til renovering af statuer ved det historiske svømmeanlæg. Disse statuer er oprindelig doneret i 20-erne til Gymnastikhøjskolen af $\mathrm{Ny}$ Carlsbergfondet”. Herved vil $\mathrm{Ny}$ Carlsbergfondet kunne "medvirke ved den nationale opgave, som er forbundet med for eftertiden at sikre Danmarks første Gymnastikhøjskole, Nordens første svømmehal samt de klassiske statuer, der er en del af helheden i det historiske skoleanlæg”, hasteansøgning til Ny Carlsbergfondet ved forstander Uffe Strandby, Ollerup d. 11/3 2002.

3 Jvf. interview med Ellen Haastrup.

4 Se internetopslaget for den fremragende udstilling på Thorvaldsens museum om Alexanderfrisen og Thorvaldsen som en egentlig kritisk oplysningskunstner, der samtidig har en autokratisk og selvdyrkende skikkelse som Napoleon som opdragsgiver: "Magtens Pris. Napoleon, Alexander den Store og Thorvaldsen" fra 22. marts 2012 til 20. januar 2013, http://thorvaldsensmuseum.dk/udstillinger/ tidligere

5 http://www.realdania.dk/Presse/Nyheder/2005/Ollerup+01-11-05.aspx

6 Det skal dog understreges, at symbolet også har været udbredt $\mathrm{i}$ andre dele af verden og $\mathrm{i}$ forskellige tidsperioder f.eks. i Indien helt op til vor tid (Achen, 1986). I oldnordisk tid afbilledes amuletsymbolet Thors hammer på 'en hagekorslignende måde' (Biedermann, 1991, s. 145).

7 Ved opvisningen ved Den nordiske olympiade i 1935 dirigerede Snoghøj Anna Krogshede sit hold stående på jorden, mens Bukh stod højt hævet på et podium, jf. filmen herfra.

8 I 1974 oprettede de tre kunstnere et "Institut for Skalakunst". 


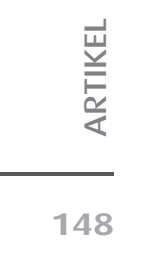

